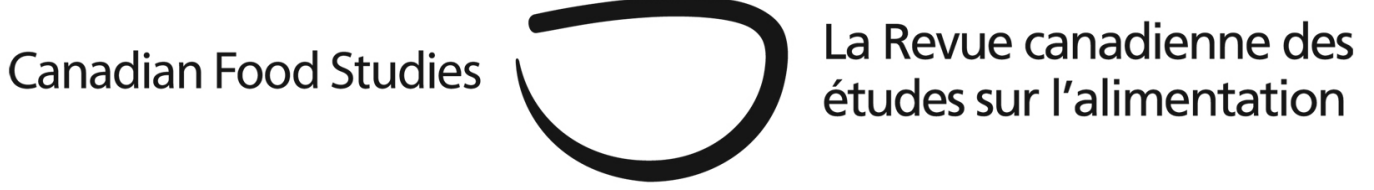

\title{
Globalization and food sovereignty: Global and local change in the new politics of food \\ Edited by Peter Andrée, Jeffrey Ayres, Michael J. Bosia, and \\ Marie-Josée Massicotte \\ University of Toronto Press, 2014: 392 Pages
}

Review by Patrick Clark, Chantal Clément, and Amanda DiVito Wilson, Carleton University

\footnotetext{
"To demand a space of food sovereignty is to demand specific arrangements to govern territory and space” (Patel, 2009, p. 667). However, the further we move into a globalized system of food and agricultural production, the more these specific arrangements come into conflict with current global systems of governance. Andrée et al.'s Globalization and Food Sovereignty provides an insightful account of the tensions and complexities of the burgeoning concept of food sovereignty. Its holistic examination of how food sovereignty plays out in both theoretical terms and in practice, in the Global North and South, and at both the local and global levels, serves as one of its greatest strengths. Through a superb set of case studies, it shows how the two themes of food sovereignty and neoliberal globalization interact, manifesting in different ways in different locales and contexts, and at times for different ends. Drawing on contributions from a range of academic disciplines, but directed specifically at political science, this book engages in a theoretically driven analysis of food sovereignty that urges us to take notice of this "new politics of food.”

Part I delves into the politics around the term food sovereignty, exploring its various theoretical and discursive debates. Though the section begins by highlighting the benefits and productivity gained by a globalized neoliberal food system, it sets the tone for the rest of the volume in problematizing that very same system. Neoliberalism stands at the forefront of the
} 
work, serving simultaneously as the arena in which food sovereignty movements operate, as well as the source of what they are working against. It is in fact the critical discourse around neoliberalism that has allowed food sovereignty movements to thrive across the globe, whether through adaptation, resistance, or co-optation.

Chapter 1 provides an insightful overview of the tensions and paradoxes inherent to the study of food, setting the stage for the remaining chapters in this section. Menser traces the development of food sovereignty, and along with many of the other authors, creates discursive space for a conception of democracy and sovereignty outside of their usual articulation within a Westphalian state system—what he calls “maximal democracy.” Indeed, Menser, MacMahon, Andrée, and Martin all move beyond the traditional boundaries of the state, whether through social networks or market entrepreneurship, to redefine notions of self-determination, participatory democracy, and space.

Zerbe puts forward a study of the global fair trade movement in contrast to the growth of the local food movement. In particular, he argues that alternative food networks, as exemplified here by the fair trade movement, limit their own success through the smaller scale of operation they favour, and also by operating within a very globalized capitalist agri-food system that is not regulated in favor of small-scale producers or agricultural workers. Zerbe's argument-that the transformative potential of these initiatives should not be overemphasized-is a welcome counterpoint to the usual emphasis placed on the small and local scale. Similarly, MacMahon provides an excellent experiential critique of neoliberalism and of the local food movement's limitation in serving as a "movement for change." She stresses the inability of alternative movements to address the underlying struggles caused by the system, not only through their lack of capacity to affect the broader policies affecting them, but also in their clinging to a more individualist and consumer-focused discourse over a more radical agrarian citizenship-based discourse, rooted in food democracy and food justice.

Part I questions the utility of "the state" as an organizing concept and the ability of the market to move beyond a capitalist and consumer-based focus, and-if so-how the state, market, and local food movement can better address the goals of food sovereignty. As expected, delving into the complexities and contradictions within the concept of food sovereignty itself is an exercise that raises more questions than answers.

Part II of the book turns its attention to how the "neoliberalization" of food and agriculture and the responding efforts at food sovereignty are manifested in practice. These processes are presented as contested and embedded rather than overarching and uniform, illustrating how different actors in different spaces "do food sovereignty” (Wright, p. 201) in the face of “actually existing neoliberalism” (Brenner \& Theodor, 2002, p. 349). In doing so, the authors are part of a broader shift towards non-linear theorizing, a very welcome step away from the tendency towards deterministic theories of agro-food studies' past (Carolan, 2013). In addition, these chapters take us beyond the material, discussing food sovereignty as both a 
practice to pursue social and environmental sustainability and a discourse mobilized to gain power and authority.

Each of the case studies brings a different context and set of actors to the discussion, highlighting the breadth and diversity of ways that food sovereignty claims and strategies have been taken up. Andrée looks at the potential for food sovereignty to be advanced through marketbased alternative agriculture in Australia, while Martin and Andrée take a critical look at how NGOs use the discourse of food sovereignty to assert power and authority in areas previously provided for by the state. In this context neoliberalism both enables and constrains food sovereignty efforts. The chapters by Wright and Knezevic widen our gaze outside of the common sites of analysis within the AFN literature to Eastern Europe and the Phillipines, and use a food sovereignty lens to understand the efforts of both farmers and consumers to challenge and circumvent neoliberal agricultural policy.

One recurring theme in this section and throughout the book is the significance of individual action - the degree to which we can understand the individual actions of producer or consumers as part of a broader movement for social change. While Andrée and Knezevic propose that the actions of "citizen-farmers" have the potential to contribute to collective goals, even if they are not described as such, the earlier chapters by Zerbe and Mahon present a less favourable assessment. Again, we are left with diverse possibilities and outcomes rather than one overarching narrative of social change.

Section Three delves into the contentious politics of food sovereignty, exploring how social movements have invoked the concept in their strategies of political and social organization. As evidenced by the case studies of farmers' movements in Vermont and France by Ayers and Bosia, and Massicotte's study of the strategies of the MST in Brazil, these politics are generally presented as forms of "localized resistance” (Ayers \& Bosia, p. 319), or "maximal democracy” (Menser, p. 60), struggles for greater control and autonomy in the face of encroaching global processes. While these tendencies reflect the broader "think global act local" rallying cry of the alter-globalization movement, local spaces can hardly ever be considered "sovereign" and this is why it is questionable how effective or significant these acts of "local resistance” are in the face of a global system. As Smythe’s chapter demonstrates, action and organizing for change needs to happen concurrently at multiple scales and levels. Smythe focuses on the question of food labeling as one mechanism which — in the vein of Karl Polanyican provide some protection from the market and the global corporate food regime. Polanyi (1957, p. 141) reminds us that "laissez-faire was planned” and Smythe’s case study of the WTO and Codex demonstrates that the global food regime has also been "planned" by the international institutional arrangements that are limiting national policy space on the issue of food labeling. As Smythe argues, resistance to these arrangements has focused on institutions both national and transnational in scope, not at the local level. McMichael also recognizes this issue in the conclusion of the book, emphasizing that the movement towards greater food sovereignty will require concurrent action and political change at multiple scales including the national level and 
the transnational level. While many food sovereignty movements draw their strength from placebased resistance, localized action may be insufficient as the sole driver of systemic change.

Food sovereignty is both a critique of neoliberal globalization and a proposal for alternative food systems outside of corporate agriculture. While many of the cases in this book demonstrate that political demands often revolve around greater autonomy and self-management, the reality is that these movements are not isolated from the national and global forces that underpin the global corporate food regime. This raises the question "what 'sovereignty' is invoked by food sovereignty?” The concept of sovereignty is used as a critique of neoliberal globalization and the loss of sovereignty over food and agriculture, however it is not clear how new sovereignties over food and agriculture are to be constructed, and what they will look like. As Hospes (2014) has argued, while food sovereignty draws on the concept of sovereignty, it refers concurrently to both a Westphalian state-centric conception of sovereignty and a plural conception of sovereignty that is not state-centered. This results in the mobilization of competing notions of sovereignty, a contradiction that is recognized and explored but not necessarily resolved by the authors in this volume. This lack of conceptual clarity may be, as Hospes suggests, part of the process of bridging divergent notions of sovereignty in new ways.

This volume showcases the richness of initiatives and forms of resistance laying claim to the concept of food sovereignty. However, the desire to make food sovereignty an inclusionary term, uniting a number of social movements' struggles around food, can be as much a weakness as a strength. Much like the growing discourse around "governance” or "sustainability," as food sovereignty plays out in the diversity of the case studies and issues surveyed here, we face an increasing diversity of definitions of the term. As Minnery (2007) writes on governance, terms seeking to encompass everything run the risk of meaning nothing. What unites food sovereignty movements is that they have grown up in opposition to the global corporate food regime described by McMichael (2005), but this does not mean that these disparate movements have the same kind of politics or even advocate for the same alternatives to the current system. It is hard to imagine that the Canadian Federation of Agriculture and MASIPAG coalition of farmers in the Philippines, both promoters of the idea of food sovereignty, would in practice find themselves on the same side of many agricultural issues-hence the dangers of stretching the concept of food sovereignty too far.

McMichael references the "elasticity" (p. 345) of the concept of food sovereignty in the book's conclusions, and while we agree with an understanding that acknowledges the multipleand sometimes divergent - ways that food sovereignty can be understood, this must be balanced against some sort of basic unity of principles rooted in actual practices and empirical realities. This "elasticity" can be a danger and it may be necessary for movements analyzed in this volume-some of which are affiliated with La Via Campesina-to be more upfront about the heterogeneity of perspectives, interests, and practices amongst their members. From this flows the question of actual strategies to achieve greater food sovereignty by unifying this diversity through action for change. Overall, while it leaves us with a breadth of new perspectives, 
Globalization and Food Sovereignty inevitably also leaves us—both as academics and practitioners - with the glaring acknowledgement of the task we have at hand in facing the growing crises of our current global food regime, as well as with more fundamental questions about the concept of food sovereignty itself.

\section{References}

Brenner, N. \& Theodore, N. (2002). Cities and the geographies of 'actually existing neoliberalism'. Antipode 34(3), 349-379.

Carolan, M. (2013). The wild side of agro-food studies: On co-experimentation, politics, change, and hope. Sociologia Ruralis 53(4), 413-431.

Hospes, O. (2014). Food sovereignty: the debate, the deadlock, and a suggested detour. Agriculture and Human Values 31,119-130.

McMichael, P. (2005). Global development and the corporate food regime. In F. H. Buttel and P. McMichael (eds.) New Directions in the Sociology of Global Development: 269-303. Emerald Group Publishing Limited.

Patel, R. (2009). What does food sovereignty look like? The Journal of Peasant Studies 36(3), 663-706.

Polanyi, K. (1957). The great transformation: The Political and Economic Origins of our Times. Boston: Beacon Hill.

Patrick Clark is a PhD candidate in Political Science at Carleton University and a researcher at the Latin American Faculty of Social Sciences (FLACSO) in Quito, Ecuador. He is currently writing his doctoral dissertation, which examines the institutionalization of food sovereignty in Ecuador.

Chantal Clément is PhD candidate in Political Science at Carleton University. Her current doctoral research compares municipal-level governance mechanisms to support the transition to sustainable food systems in Canada and the EU.

Amanda DiVito Wilson is a PhD candidate in Sociology at Carleton University. Her research explores how post-capitalist possibilities are reconciled with the day-to-day negotiations of earning a living in food-based livelihoods. 